\title{
PENINGKATAN PRODUKSI TANAMAN DENGAN POLA TANAM TUMPANGSARI JAGUNG DAN PADI GOGO PADA BERBAGAI JARAK TANAM
}

\section{INCREASED CROP PRODUCTION WITH TUMPANGSARI PLANTING PATTERNS OF CORN AND PADDY GOGO AT VARIOUS PLANTING DISTANCES}

\author{
Sution $\square$, Akhmad Musyafak dan Sri Sunardi \\ Balai Pengkajian Teknologi Pertanian (BPTP) Kalimantan Barat \\ Corresponding author: sution@pertanian.go.id
}

\begin{abstract}
ABSTRAK
Penelitian ini bertujuan untuk mengetahui pola tanam tumpangsari jagung dengan tanaman padi gogo pada jarak yang sesuai, mengetahui nilai kesetaraan lahan (NKL) pola tanam tumpangsari jagung dengan padi gogo serta melihat kelayakan usahatani tumpangsari jagung dengan padi gogo. Penelitian ini menggunakan Rancangan Acak Kelompok yang terdiri dari 4 perlakuan tanaman Monokultur, tumpangsari jagung dengan padi gogo jarak 3 baris, jagung dengan padi gogo jarak 6 baris dan jagung dengan padi gogo jarak 9 baris. Kemudian diulang sebanyak 6 kali, sehingga menghasilkan 24 petak perlakuan. Hasil penelitian menunjukkan bahwa produktivitas padi gogo yang ditanam secara monokultur dan tumpangsari dengan jagung tertinggi tanam monokultur dan jarak padi gogo 9 baris masingmasing $3.745 \mathrm{t} \mathrm{ha}^{-1}$ dan $3.314 \mathrm{t} \mathrm{ha}^{-1}$. Untuk pola tanam tumpangsari jagung dan padi gogo terhadap produktivitas jagung tidak terjadi perbedaan antara tanaman monokultur maupun jagung ditanam diantara tanaman padi gogo $3-9$ baris. Nilai kesetaraan lahan tertinggi pada pola tanam tumpangsari jagung dengan padi gogo jarak 9 baris. Demkian juga hasil analisis usahatani tumpangsari jagung dengan padi gogo berdasarkan $\mathrm{R} / \mathrm{C}$ rasio atas biaya tunai dan total tertinggi pada pola tanam tumpangsari jagung dengan padi gogo jarak 9 baris yaitu masing-masing 3,21 dan 2,29.
\end{abstract}

Kata Kunci : Tumpangsari; Jagung; Padi Gogo; Jarak Tanam; NKL.

\section{ABSTRACT}

This study destinatio to determine the intercropping pattern of maize with upland rice plants at an appropriate distance, to determine the land equality value (NKL) of intercropping corn with upland rice and to see the feasibility of intercropping corn with upland rice. This study used a randomized block design consisting of 4 treatments of monoculture plants, intercropping of maize with 3 rows of spaced upland rice, 6 rows of maize with upland rice and 9 rows of upland rice. Then it was repeated 6 times, resulting in 24 treatment plots. The results showed that the productivity of upland rice grown by monoculture and intercropping with the highest maize was monoculture and 9 rows of upland rice spacing were 3,745 tha-1 and 3,314t ha-1, respectively. For the intercropping pattern of maize and upland rice on maize productivity there was no difference between monoculture and maize grown between 3 - 9 rows of upland rice. The highest land equality value was in the intercropping pattern of maize with upland rice spacing 9 rows. Likewise, the results of the analysis of the intercropping of maize with upland rice based on the $R$ / $C$ ratio of cash costs and the highest total were the intercropping patterns of maize with upland rice spacing 9 rows, namely 3.21 and 2.29 respectively.

Keywords: Tumpangsari; Corn; Gogo Rice; Plant Distance; NKL. 


\section{PENDAHULUAN}

Seiring dengan peningkatan jumlah penduduk, maka kebutuhan pangan juga semakin meningkat. Salah satu upaya peningkatan produksi pangan melalui intensifikasi yaitu dengan perbaikan teknologi budidaya. Status luas lahan kepemilikan petani di Indonesia tergolong rendah untuk tanaman padi $<0,5$ ha, sedangkan untuk palawija 0,50 - 0,99 ha (Badan Pusat Statistik, 2018). Tumpangsari merupakan salah satu cara untuk meningkatkan produktivitas tanaman dan efisiensi penggunaan lahan (Susanti et al., 2014). Tumpangsari merupakan pola tanam pada sebidang lahan yang ditanam lebih dari satu jenis tanaman pada waktu yang sama (Putra et al., 2017). Pola tanam tumpangsari juga dapat mengurangi resiko gagal panen dan serangan Oragnisme Penggangu Tanaman (OPT) karena berbagai jenis tanaman yang beragam. Keuntungan pola tanam tumpangsari mencapai $81 \%$ dibanding cara tanam monokultur (Hermawati, 2016). Pola tanam tumpangsari jagung dengan padi gogo saling menguntungkan karena padi pada intensitas cahaya rendah masih bisa berproduksi dengan baik. Tujuan penelitian ini untuk menghasilkan pola tanam tumpangsari jagung dengan padi gogo pada jarak yang sesuai, mengetahui nilai kesetaraan lahan (NKL) pola tanam tumpangsari jagung dengan padi gogo serta melihat kelayakan usahatani tumpangsari jagung dengan padi gogo.

\section{METODE PENELITIAN}

Bahan dan Metode

Penelitian ini dilaksanakan di wilayah perbatasan Kabupaten Sanggau tepatnya di Desa Kenaman, Kec. Sekayam, Kab. Sanggau. Pada bulan Oktober 2018 Februari 2019. Bahan yang digunakan benih jagung varietas Bima 2 sedangkan benih padi gogo varietas Situ Patenggang. Pupuk menggunkan pupuk kandang ayam, pupuk anorganik, insektisida, fungisida dan rodentisida.

Penelitian ini menggunakan Rancangan Acak Kelompok yang terdiri dari 4 perlakuan tanaman monokultur padi gogo $20 \mathrm{~cm}$ x $20 \mathrm{~cm}$ populasi per ha 250.000 rumpun, tumpangsari jagung dengan padi gogo jarak 3 baris yaitu 160 $\mathrm{cm}(20 \mathrm{~cm} \times 10 \mathrm{~cm} \times 50 \mathrm{~cm})$, jumlah rumpun per baris 150 dan jumlah dalam baris 1.000 rumpun, sehingga populasi per ha 150.000 rumpun, tumpangsari jagung dengan padi gogo jarak 6 baris yaitu 160 $\mathrm{cm}(20 \mathrm{~cm} \times 10 \mathrm{~cm} \times 50 \mathrm{~cm})$, jumlah rumpun per baris 228 dan jumlah dalam baris 1.000 rumpun, populasi per ha 228.000 rumpun dan tumpangsari jagung 
dengan padi gogo jarak 9 baris $160 \mathrm{~cm} \mathrm{(20}$ $\mathrm{cm} \times 10 \mathrm{~cm}$ x $50 \mathrm{~cm}$ ), jumlah rumpun per baris 279 dan jumlah dalam baris 1.000 rumpun, populasi per ha 279.000 rumpun. Sedangkan untuk tanaman jagung monokultur dengan jarak $70 \mathrm{~cm}$ x $20 \mathrm{~cm}$, jumlah benih per lobang tanam 1 biji sehingga populasi per ha 71.000 tanaman. Tumpangsari jagung dengan padi gogo yang ditanam diantara padi gogo 9 baris yaitu $160 \mathrm{~cm}(60 \mathrm{~cm}$ x $20 \mathrm{~cm}$ x $50 \mathrm{~cm})$ dengan jumlah benih per lobang tanam 2 biji. Jumlah tanaman per baris 124 dan jumlah dalam baris 1.000 tanaman sehingga populasi per ha 124.000 tanaman. Tumpangsari jagung diantara padi gogo 6 baris yaitu $160 \mathrm{~cm}(60 \mathrm{~cm}$ x $20 \mathrm{~cm}$ x 50 cm) ditanam 2 biji, dengan jumlah tanaman per baris 152 dan jumlah dalam baris 1.000 tanaman sehingga populasi per ha 154.000 tanaman. Tumpangsari jagung diantara padi gogo 3 baris yaitu $160 \mathrm{~cm}$ $(60 \mathrm{~cm} \times 20 \mathrm{~cm} \times 50 \mathrm{~cm})$ ditanam 2 biji, dengan jumlah tanaman per baris 200 dan jumlah dalam baris 1.000 tanaman sehingga populasi per ha 200.000 tanaman. Kemudian diulang sebanyak 6 kali, sehingga menghasilkan 24 petak perlakuan.

Variabel yang diamati pada tanaman padi gogo (1) tinggi tanaman (cm), (2) jumlah anakan (anakan), (3) panjang malai $(\mathrm{cm})$, (4) jumlah gabah isi (biji), (5) presentase gabah hampa (\%), (6) jumlah gabah per malai (biji), (7) jumlah malai per rumpun (malai) (8) Bobot 1000 butir (g) (9) produktivitas ( $\left.\mathrm{t} \mathrm{ha}^{-1}\right)$. Sedangkan variabel untuk tanaman jagung yaitu (1) tinggi tanaman (cm), (2) tinggi letak tongkol (cm), (3) rasio tinggi tanaman dengan tinggi letak tongkol $(\mathrm{cm})$, (4) panjang tongkol (cm), (5) lingkar tongkol (cm), (6) jumlah biji per baris (biji), (7) jumlah biji per lingkar tongkol (biji) (8) jumlah biji per tongkol (biji) (9) kadar air (\%) (10) bobot 1000 butir (g), dan (11) hasil produksi biji pipil ( $\left.\mathrm{t} \mathrm{ha}^{-1}\right)$.

\section{HASIL DAN PEMBAHASAN}

Komponen Pertumbuhan dan Produksi

\section{Tanaman Padi Gogo}

Data pada Tabel 1 menunjukkan bahwa tidak terdapat perbedaan tinggi tanaman dan jumlah anakan padi gogo yang ditanam secara monokultur maupun ditanam secara tumpangsari dengana jagung dengan jarak 3-9 baris. Sedangkan pengamatan terhadap panjang malai menunjukkan tertinggi padi gogo ditanam secara monokultur dan tumpangsari dengan jagung jarak 6-9 baris, secara signifikan berpengaruh terhadap jarak tanam 3 baris. 
Tabel 1. Rata-rata tinggi tanaman, jumlah anakan dan panjang malai padi gogo dengan jarak beberapa baris diantara jagung.

\begin{tabular}{|c|c|c|c|}
\hline Perlakuan & $\begin{array}{l}\text { Tinggi tanaman } \\
\text { (cm) }\end{array}$ & $\begin{array}{c}\text { Jumlah anakan } \\
\text { (anakan) }\end{array}$ & $\begin{array}{l}\text { Panjang Malai } \\
(\mathrm{cm})\end{array}$ \\
\hline Monokultur & $137.67 \mathrm{a}$ & 14.83 & $23.83 \quad \mathrm{a}$ \\
\hline Padi Gogo 9 baris & $140.83 \quad \mathrm{a}$ & 13.83 & 23.19 \\
\hline Padi Gogo 6 baris & 142.33 & 12.67 & $21.67 \mathrm{ab}$ \\
\hline Padi Gogo 3 baris & 144.17 & 11.50 & 19.59 \\
\hline
\end{tabular}

Keterangan : Angka didampingi huruf yang sama pada kolom yang sama berarti tidak berbeda nyata menurut uji BNT $5 \%$.

Data pada Tabel 2 menunjukkan pola yang sama terhadap produktivitas dan jumlah gabah isi per malai tertinggi pada tanaman monokultur dan padi gogo 9 baris dan secara signifikan berpengaruh terhadap jarak tanam $3-6$ baris. Presentase gabah hampa padi gogo yang ditanam secara tumpangsari dengan tanaman jagung 3 dan 6 baris mempunyai presentses gabah hama tertinggi 44,93\% dan $35,33 \%$, secara signifikan berpengaruh terhadap padi gogo ditanam secara monokultur dan 9 baris yaitu 20,45 $\%$ dan 27,64\%. Semakin rapat jarak antar jagung maka semakin tinggi presentase gabah hampa, ini disebabkan semakin sedikit cahaya matahari diterima oleh tanaman. Jumlah gabah per malai, menujukkan tidak terjadi perbedaan antara padi gogo ditanam secara monokultur dan tumpangsari diantara tanaman jagung dengan jarak tanam padi gogo 3 hingga 9 baris tanaman. Jumlah malai per rumpun dan bobot 1000 butir mempunyai pola yang sama tertinggi pada padi gogo ditanam secara monokultur dan diantara jagung 6-9 baris.

Komponen Pertumbuhan dan Produksi

\section{Tanaman Jagung}

Data pada Tabel 3 memperlihatkan bahwa tinggi tanaman, rasio tinggi tanaman dengan tinggi letak tongkol, panjang tongkol dan panjang lingkar tongkol jagung ditanam secara monokultur dan tumpangsari diantara tanaman padi gogo 3 hingga 9 baris tidak terjadi perbedaan antar perlakuan. Sedangkan letak tongkol jagung tertinggi pada perlakukan jagung ditanam secara tumpangsari diantara tanaman padi gogo pada jarak 3 dan 9 baris masing-masing $122,50 \mathrm{~cm}$ dan $118,33 \mathrm{~cm}$ secara signifikan berpengaru pada tanaman 
jagung ditanam secara monokultur 100,00 cm dan diantara padi gogo 6 baris 99,17 $\mathrm{cm}$. Tinggi letak tongkol berhubungang dengan proses peyerbukan tanaman, dimana bunga betina dekat dengan bunga jantan memiliki peluang yang lebih besar untuk diserbuki (Rembang, 2010).

Tabel 2. Rata-rata jumlah gabah isi per malai, presentase gabah hampa, jumlah gabah per malai, jumlah malai per rumpun, bobot 1000 butir dan produktivitas.

\begin{tabular}{|c|c|c|c|c|c|c|c|c|c|c|c|c|}
\hline \multirow[b]{2}{*}{ Monokultur } & \multicolumn{2}{|c|}{$\begin{array}{l}\text { Jlh gabah isi } \\
\text { per malai } \\
\text { (butir) }\end{array}$} & \multicolumn{2}{|c|}{$\begin{array}{l}\text { Presentase } \\
\text { gabah } \\
\text { hampa }(\%)\end{array}$} & \multicolumn{2}{|c|}{$\begin{array}{l}\text { Jlh gabah } \\
\text { per malai } \\
\text { (butir) }\end{array}$} & \multicolumn{2}{|c|}{$\begin{array}{l}\text { Jlh malai } \\
\text { per rumpun } \\
\text { (malai) }\end{array}$} & \multicolumn{2}{|c|}{$\begin{array}{l}\text { Bobot } \\
1000 \text { butir } \\
\text { (g) }\end{array}$} & \multicolumn{2}{|c|}{$\begin{array}{c}\text { Produktivitas } \\
(\mathrm{t} / \mathrm{ha})\end{array}$} \\
\hline & 103.53 & $\mathrm{a}$ & 20.45 & $\mathrm{c}$ & 130.54 & $\mathrm{a}$ & 11.50 & $\mathrm{a}$ & 24.98 & $\mathrm{a}$ & 3,745 & $\mathrm{a}$ \\
\hline Padi Gogo 9 baris & 99.56 & $a b$ & 27.64 & $\mathrm{bc}$ & 141.52 & $\mathrm{a}$ & 11.17 & $\mathrm{a}$ & 24.51 & $\mathrm{a}$ & 3,134 & $a b$ \\
\hline Padi Gogo 6 baris & 83.78 & $\mathrm{~b}$ & 35.53 & $a b$ & 130.22 & $\mathrm{a}$ & 8.83 & $a b$ & 23.39 & $a b$ & 2,331 & $\mathrm{~b}$ \\
\hline Padi Gogo 3 baris & 56.12 & $\mathrm{c}$ & 44.93 & $\mathrm{a}$ & 103.38 & $\mathrm{a}$ & 7.00 & $\mathrm{~b}$ & 21.72 & $\mathrm{~b}$ & 1,098 & $\mathrm{c}$ \\
\hline BNT $(5 \%)$ & \multicolumn{2}{|c|}{17.54} & \multicolumn{2}{|c|}{12.07} & \multicolumn{2}{|l|}{ tn } & \multicolumn{2}{|c|}{2.93} & \multicolumn{2}{|c|}{2.23} & \multicolumn{2}{|l|}{947} \\
\hline
\end{tabular}

Berdasarkan hasil analisis statistik pada Tabel 4 menunjukkan bahwa jumlah biji per lingkar tongkol, kadar air, bobot 1000 butir dan produktivitas tanaman yang ditanam secara monokultur maupun tumpangsari dengan padi gogo pada jarak
3 - 9 baris tidak terdapat perbedaan antar perlakuan. Sedangkan jumlah biji per baris tongkol dan jumlah biji per tongkol mempunyai pola yang sama yaitu tertinggi pada jagung ditanam secara monokultur dan tumpangsari dengan padi gogo 9 baris.

Tabel 3. Rata-rata tinggi tanaman, tinggi letak tongkol, rasio tinggi tanaman dengan tinggi letak tongkol, panjang tongkol dan panjang lingkar tongkol jagung diantara beberapa baris padi gogo.

\begin{tabular}{|c|c|c|c|c|c|c|c|c|c|c|}
\hline \multirow[b]{2}{*}{ Monokultur } & \multicolumn{2}{|c|}{$\begin{array}{c}\text { Tinggi } \\
\text { Tanaman } \\
(\mathrm{cm})\end{array}$} & \multicolumn{2}{|c|}{$\begin{array}{l}\text { Tinggi } \\
\text { Letak } \\
\text { Tongkol } \\
(\mathrm{cm}) \\
\end{array}$} & \multicolumn{2}{|c|}{$\begin{array}{c}\text { Rasio Tinggi vs } \\
\text { Tinggi Letak } \\
\text { Tongkol }(\mathrm{cm})\end{array}$} & \multicolumn{2}{|c|}{$\begin{array}{l}\text { Panjang } \\
\text { tongkol } \\
(\mathrm{cm})\end{array}$} & \multicolumn{2}{|c|}{$\begin{array}{l}\text { Panjang } \\
\text { lingkar } \\
\text { tongkol } \\
(\mathrm{cm}) \\
\end{array}$} \\
\hline & 231.67 & $\mathrm{a}$ & 100.00 & b & 43.42 & $\mathrm{a}$ & 18.00 & $a$ & 15.83 & $\mathrm{a}$ \\
\hline Diantara Padi Gogo 9 baris & 244.17 & a & 118.33 & $\mathrm{a}$ & 48.83 & a & 17.42 & $\mathrm{a}$ & 15.08 & $\mathrm{a}$ \\
\hline Diantara Padi Gogo 6 baris & 246.67 & $\mathrm{a}$ & 99.17 & b & 40.29 & $\mathrm{a}$ & 16.58 & $\mathrm{a}$ & 14.33 & $\mathrm{a}$ \\
\hline Diantara Padi Gogo 3 baris & 226.67 & $\mathrm{a}$ & 122.50 & $\mathrm{a}$ & 54.07 & $\mathrm{a}$ & 16.75 & $\mathrm{a}$ & 14.92 & $\mathrm{a}$ \\
\hline BNT $5 \%$ & $\operatorname{tn}$ & & 13.82 & & $\operatorname{tn}$ & & tn & & $\operatorname{tn}$ & \\
\hline
\end{tabular}

Keterangan : Angka didampingi huruf yang sama pada kolom yang sama berarti tidak berbeda nyata menurut uji BNT 5\%. 
Tabel 4. Rata-rata jumlah biji per lingkar tongkol, jumlah biji per baris tongkol, jumlah biji per tongkol, kadar air, bobot 1000 butir dan produktivitas tanaman jagung ditanam diantara beberapa baris padi gogo.

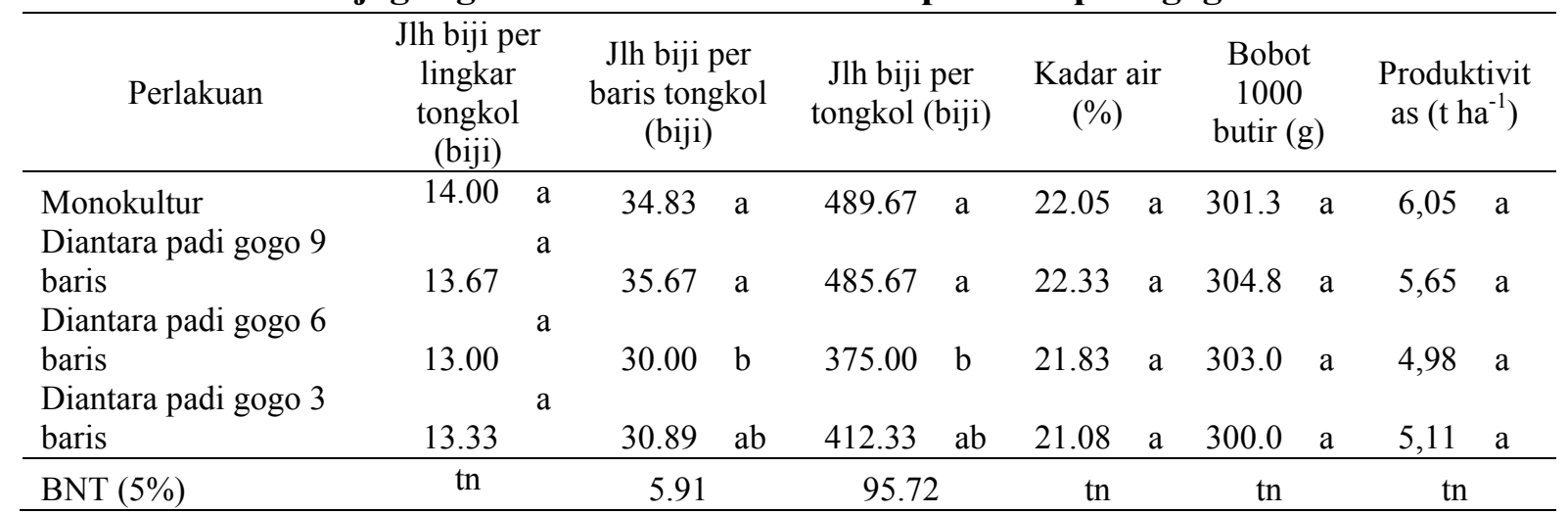

Keterangan : Angka didampingi huruf yang sama pada kolom yang sama berarti tidak berbeda nyata menurut uji BNT 5\%.

Nilai Kesetaraan Lahan Tumpangsari

\section{Jagung dengan Padi Gogo}

Data pada Tabel 5 menunjukkan bahwa tumpangsari jagung dengan padi gogo 9 baris mempunyai nilai kesetaraan lahan tertinggi (1.77). Jarak tanam padi gogo yang agak lebar, meyebabkan intensitas cahaya matahri ditermima tanaman cukup tinggi, sehingga proses fotosinstesis berjalan dengan baik.
Menurut Dewi et al., (2014) bahwa tumpangsari jagung manis dengan padi gogo mempunyai nilai kesetaraan lahan tertinggi pada perlakuan jarak tanam jagung $50 \mathrm{~cm}$ x $30 \mathrm{~cm}$. Menurut Lestari et al., (2019) bahwa tumpangsari jagung dengan kacang hijau mempunyai nilai kesetaraan lahan tertinggi pada jarak tanam jagung $90 \mathrm{~cm} \times 30 \mathrm{~cm}$ yaitu1,5

Tabel 5. Nilai rata-rata hasil perhitungan keseluruhan NKL tumpangsari jagung dengan padi gogo dengan jarak tanam berbeda.

\begin{tabular}{lc}
\hline \multicolumn{1}{c}{ Kombinasi Perlakuan } & NKL \\
\hline Tumpangsari Jagung + padi gogo 9 baris & 1.77 \\
Tumpangsari Jagung + padi gogo 6 baris & 1.44 \\
Tumpangsari Jagung + padi gogo 3 baris & 1.14 \\
\hline
\end{tabular}

Analisis Usahatani Tumpangsari Jagung dengan Padi Gogo

Analisis $\mathrm{R} / \mathrm{C}$ rasio digunakan untuk menunjukan perbandingan antara penerimaan dan biaya, sehingga dapat diketahui apakah usahatani yang diusahakan menguntungkan atau tidak. Apabila nilai $\mathrm{R} / \mathrm{C}$ lebih dari satu maka 
usahatani tersebut dikategorikan menguntungkan untuk diusahakan. Nilai $\mathrm{R} / \mathrm{C}$ rasio atas biaya tunai dan atas biaya total tertinggi pada tumpangsari jagung dengan padi gogo dengan jarak 9 baris masing-masing 3.21 dan 2.29. Setiap satu rupiah biaya tunai dan total yang dikeluarkan akan memberikan pendapatan Rp. 3.21 atas biaya tunai dan Rp. 2.29 atas biaya total. Tanaman padi gogo secara monokultur mempunyai nilai $\mathrm{R} / \mathrm{C}$ rasio pada atas biaya tunai 3.08 terjadi perbedaan cukup jauh dengan $\mathrm{R} / \mathrm{C}$ rasio atas biaya total 1.92 hal ini menunjukkan untuk usahatni padi gogo lebih banyak menggunakan biaya tenaga kerja dari dalam keluarga. Berdasarkan nilai $\mathrm{R} / \mathrm{C}$ rasio usahatani tumpangsari jagung dengan kacang tanah lebih tinggi 1.90 dibanding dengan jagung secara monokultur 1.70 (Putri, 2011).

Tabel 6. Analisis Usahatani Tumpangsari Padi Gogo Beberapa Jarak Tanam diantara Tanaman Jagung

\begin{tabular}{|c|c|c|c|c|c|c|c|c|c|c|c|}
\hline \multirow{2}{*}{ No } & \multirow{2}{*}{$\begin{array}{c}\text { Uraian } \\
\text { Kegiatan }\end{array}$} & \multicolumn{2}{|c|}{ Monokultur Padi Gogo } & \multicolumn{2}{|c|}{ Monokultur Jagung } & \multicolumn{2}{|c|}{ Padi Gogo 9 baris } & \multicolumn{2}{|c|}{ Padi Gogo 6 baris } & \multicolumn{2}{|c|}{ Padi Gogo 3 baris } \\
\hline & & Input & Output & Input & Output & Input & Output & Input & Output & Input & Output \\
\hline \multirow[t]{4}{*}{ I } & Variabel Biaya & & & & & & & & & & \\
\hline & Sarana Saprodi & $1,962,000$ & & $4,692,500$ & & $5,664,500$ & & $5,664,500$ & & $5,664,500$ & \\
\hline & $\begin{array}{l}\text { Upah Tenagan } \\
\text { Kerja }\end{array}$ & $5,020,000$ & & $5,620,000$ & & $8,320,000$ & & $8,320,000$ & & $8,320,000$ & \\
\hline & Biaya Tetap & 816,778 & & $1,002,981$ & & $1,156,971$ & & $1,156,971$ & & $1,156,971$ & \\
\hline II & Biaya Tunai & $4,857,000$ & & $8,147,500$ & & $10,799,500$ & & $10,799,500$ & & $10,799,500$ & \\
\hline III & Total Biaya & $7,783,778$ & & $11,315,481$ & & $15,141,471$ & & $15,141,471$ & & $15,141,471$ & \\
\hline \multirow[t]{3}{*}{ IV } & $\begin{array}{l}\text { Produksi } \\
\text { (kg/ha) }\end{array}$ & & & & & & & & & & \\
\hline & Jagung & & & 6,051 & & 5,632 & & 5,166 & & 5,074 & \\
\hline & Padi Gogo & 3,745 & & & & 3,034 & & 2,331 & & 1,098 & \\
\hline \multirow[t]{4}{*}{$\mathrm{V}$} & Pendapatan & & & & & & & & & & \\
\hline & Jagung & & & & $24,204,000$ & & $22,528,000$ & & $20,664,000$ & & $20,296,000$ \\
\hline & Padi Gogo & & $14,980,000$ & & & & $12,136,000$ & & $9,324,000$ & & $4,392,000$ \\
\hline & $\begin{array}{l}\text { Total } \\
\text { Pendapatan }\end{array}$ & & $14,980,000$ & & $24,204,000$ & & $34,664,000$ & & $29,988,000$ & & $24,688,000$ \\
\hline \multirow[t]{3}{*}{ VI } & Keuntungan & \multicolumn{10}{|c|}{$19,522,529$} \\
\hline & Tunai & & $10,123,000$ & & $16,056,500$ & & $23,864,500$ & & $19,188,500$ & & $13,888,500$ \\
\hline & Total & & $7,196,223$ & & $12,888,519$ & & $19,522,529$ & & $14,846,529$ & & $9,546,529$ \\
\hline \multirow[t]{3}{*}{ VII } & R/C Rasio & & & & & & & & & & \\
\hline & $\begin{array}{l}\mathrm{R} / \mathrm{C} \text { Rasio atas } \\
\text { biaya Tunai }\end{array}$ & \multicolumn{2}{|c|}{3.08} & \multicolumn{2}{|c|}{2.97} & \multicolumn{2}{|c|}{3.21} & \multicolumn{2}{|c|}{2.78} & \multicolumn{2}{|c|}{2.29} \\
\hline & $\begin{array}{l}\mathrm{R} / \mathrm{C} \text { Rasio atas } \\
\text { biaya Total }\end{array}$ & \multicolumn{2}{|c|}{1.92} & \multicolumn{2}{|c|}{2.14} & \multicolumn{2}{|c|}{2.29} & \multicolumn{2}{|c|}{1.98} & \multicolumn{2}{|c|}{1.63} \\
\hline
\end{tabular}


Komponen Pertumbuhan dan Produksi

\section{Tanaman Padi Gogo}

Tinggi tanaman padi dapat dipengaruhi oleh intensitas cahaya matahari yang diterima tanaman. Semakin sedikit radiasi matahari yang diterima oleh tanaman padi, maka pertumbuhan tanaman padi lebih tinggi. Tanaman yang kurang mendapatkan cahaya pertumbuhannya lebih cepat, namun tanamannya kurus, daunnya pucat dan tidak berkembang karena kurang klorofil, hal ini disebabkan auxin merangsang pemajangan sel-sel tanaman sehingga tumbuh lebih panjang (Maghfiroh, 2017). Padi ditanam dengan intensitas yang rendah $50 \%$ mempunyai tinggi tanaman 118, $03 \mathrm{~cm}$, sedangkan tanpa naungan dan $25 \%$ dinaungi lebih rendah masing-masing $116,47 \mathrm{~cm}$ dan 109 , $39 \mathrm{~cm}$ (Alridiwirsah et al.,2015)

Jumlah anakan padi gogo tidak terdapat perbedaan ditanam secara tumpangsari maupun monokultur. Hasil penelitian yang sama ditunjukan oleh Dewi et al., (2014) bahwa padi gogo yang ditanam diantara jagung manis dengan berbeagai jarak tanam tidak terjadi perbedaan terhadap jumlah anakan. Demikian juga menurut Susilo dan Parwito, (2013) bahwa jumlah anakan padi gogo ditanam secara tumpangsari dengan kedelai dengan waktu tanam yang berbeda tidak terjadi perbedaan.
Intensitas cahaya matahari yang diterima oleh tanaman sangat mempengaruhi terhadap panjang malai padi gogo. Pada jarak tanam padi gogo 3 baris diantara jagung, intensitas cahaya matahari yang diterima tanaman sedikit, sehingga meyebabkan malai lebih pendek. Menurut Khairunnisa (2019) semakin tinggi tingkat naungan maka panjang malai yang dihasilkan semakin pendek.

Jumlah gabah isi per malai pada tanaman monokultur dan padi gogo 9 baris diantara tanaman jagung masing-masing 103,53 biji dan 99,56 biji, sedangkan padi gogo 3 - 6 baris maing-masing 56,12 biji dan 83,78 biji (Tabel 2). Padi yang ditanam dibawah naungan 50\% mempunyai jumlah gabah isi 102,92 biji lebih rendah jika dibanding padi yang ditanam dengan naungan $25 \%$ dan tanpa naungan 108,92 biji dan 127,19 biji (Alridiwirsah et al., 2015).

Padi gogo ditanam secara monokultur dan tumpangsari diantara tanaman jagung dengan jarak tanam padi gogo 6 hingga 9 baris tanaman masingmasing 11,50 malai, 11,17 malai dan 8,83 malai, secara signifikan berpengaruh terhadap padi gogo ditanam dengan jarak 3 baris 7,0 malai (Tabel 2). Jumlah anakan produktif padi sangat dipengaruhi intesitas cahaya yang diterima oleh tanaman. Menurut Hafni et al., (2019) jumlah 
anakan produktif dengan intsnitas cahaya rendah 50\% lebih sedikit dibanding padi ditanam ditempat terbukan dan dibawah naungan $25 \%$.

Berdasarkan hasil analisis statistik bobot 1000 butir terhadap jarak tanam padi gogo secara monokultur dan tumpangsari dengan jarak $6-9$ baris lebih tinggi masing-masing 24,98 g, 24,51 g dan 23,39 g signifikan terhadap padi gogo ditanam secara tumpangsari dengan jarak 3 baris 21,72 g (Tabel 2). Bobot 1000 butir gabah padi gogo ditanam secara tumpangsari dengan jagung manis dengan jarak tanam berbeda 17,54 - 20,50 g (Dewi et al., 2014).

$$
\text { Produktivitas padi gogo }
$$

berdasarkan hasil ubinan untuk pola tanam monokultur ukuran ubinan 2,5 $\mathrm{m} \mathrm{x} \mathrm{2,5=}$ $6,25 \mathrm{~m}^{2}$, sedangkan pola tanam tumpangsari jagung dengan padi gogo 3 baris ukuran ubinan $1,6 \mathrm{~m} \times 5 \mathrm{~m}=8 \mathrm{~m}^{2}$, untuk jarak tanam padi gogo 6 baris diantara jagung dengan ukuran ubinan 2,2 $\mathrm{m} \times 4 \mathrm{~m}=8,8 \mathrm{~m}^{2}$, sedangkan jarak tanam padi gogo 9 baris ukuran 2,8 $\mathrm{m}$ x $3 \mathrm{~m}=8,4$ $\mathrm{m}^{2}$. Berdasarkan hasil ubinan produktivitas padi gogo tertinggi pada pola tanam monokultur 3,75 $\mathrm{t} \mathrm{ha}^{-1}$ dan tumpangasri jagung dengan padi gogo jarak tanam 9 baris $3,13 \mathrm{t} \mathrm{ha}^{-1}$, secara signifikan berpengaruh terhadap padi gogo ditanam dengan jarak 6 baris dan 3 baris masingmasing 2,33 $\mathrm{t} \mathrm{ha}^{-1}$ dan $1,10 \mathrm{t} \mathrm{ha}^{-1}$ (Tabel 2).
Produksi padi hitam ditanam tumpangsari dengan jagung yaitu $1,38-2,18 \mathrm{t} \mathrm{ha}^{-1}$ (Saputri et al., 2018). Padi gogo yang ditanam tumpangsari dengan jagung manis pada beberapa jarak tanam mempunyai produksi antara 2,35-2,87 $\mathrm{t} \mathrm{ha}^{-1}$ (Dewi et al., 2014).

\section{Komponen Pertumbuhan dan Produksi Tanaman Jagung}

Tinggi tanaman jagung ditanam secara monokultur dan tumpangsari diantara tanaman padi 3 hingga 9 baris antara 226,67 - 246,67 cm. Hasil penelitian yang sama terhadap tinggi tanaman jagung ditunjukan oleh Yuwariah et al., (2017) bahwa tinggi tanaman jagung yang ditanam secara tumpangsari dengan kedelai tidak terjadi perbedaan antar beberapa galur dengan tinggi antara 170,63 - 259,00 cm. Rasio tinggi tanaman dengan tinggi letak tongkol pada tanaman jagung yang ditanam secara monokultur dan tumpangsari dengan padi gogo jarak 3-9 baris tidak terjadi perbedaan, dengan rasio 40,29 - 54,07. Panjang tongkol jagung yang ditanam secara monokultur dan tumpangsari dengan padi gogo jarak $3-9$ baris antara 16,58 $\mathrm{cm}-18,00 \mathrm{~cm}$ (Tabel 3). Menurut Yuwariah et al., (2017) bahwa jagung yang ditanam tumpangsari dengan kedelai tidak terjadi perbedaan terhadap panjang tongkol 11,62 $\mathrm{cm}-19,20 \mathrm{~cm}$. 
Panjang tongkol berpeluang terhadap peningkatan produksi jagung (Noviana dan Ishaq, 2011). Data lingkar tongkol jagung terhadap jagung ditanam secara monokultur dan tumpangsari dengan padi gogo jarak 3-9 baris yaitu $14,33 \mathrm{~cm} \mathrm{-}$ $15,83 \mathrm{~cm}$ (Tabel 3). Diameter tongkol jagung yang ditanam secara tumpangsari dengan padi hitam tidak berbeda nyata antar perlakuan, dengan diameter antara 2,15-3,21 cm (Saputri et al., 2018).

Jumlah biji jagung ditanam secara monokultur dan tumpangsari diantara padi 3-9 baris antara 13,00 biji - 14,00 biji. Jagung ditanam dengan jarak berbeda mempunyai jumlah biji per baris 14,5 15,3 biji (Bhato, 2016). Jumlah biji per baris tertinggi pada jagung ditanam secara monokultur dan tumpangsari diantara padi gogo 9 baris yaitu masing-masing 34,83 biji dan 35,67.Jumlah biji per tongkol tertinggi pada jagung ditanam secara monokultur dan tumpangsari diantara padi gogo 9 baris yaitu masing-masing 489, 67 biji dan 485,67 biji. Bobot 1000 butir jagung yang ditanam secara monokultur dan tumpangsari dengan padi gogo jarak 3 - 9 baris menunjukkan tidak terdapat perbedaan antar perlakuan dengan bobot 300,0 g - 304,8 g. Tumpangsari jagung dengan bawang prei pada beberapa jarak tanam menunjukkan tidak terdapat perbedaan terhadap bobot 1000 butir
366,25 g - 382,38 g (Putra et al., 2017). Menurut Pratiwi (2012), semakin lebar jarak tanaman jagung tumpangsari dengan kedelai mempunyai bobot 1000 butir semakin tinggi. Produktivitas jagung yang ditanam tumpangsari diantara padi gogo 3 - 9 baris tidak terdapat perbedaan antar perlakuan dengan produktivitas antara 5,07 $-5,63 \mathrm{t} \mathrm{ha}^{-1}$ (Tabel 4). Pengaturan jarak tanam jagung tidak terjadi perbedaan yang nyata terhadap pertumbuhan dan hasil tanaman jagung (Aminah et al., 2013). Penanaman jagung dengan jarak tanam yang berbeda tidak memberikan pengaruh yang nyata terhadap bobot pipil kering pertanaman 120,4 - 133,1 g (Bhato, 2016). Jarak tanam yang rapat meningkatkan populasi tanaman sehingga dapat meningkatkan produksi tanaman, namun jika populasi tanaman melampaui daya dukung lahan akan dapat menurunkan produksi karena terjadi kompotensi yang kuat antar tanaman (Aisyah dan Herlina, 2018).

\section{KESIMPULAN}

1. Tumpangsari jagung dengan padi gogo pada jarak 9 baris dan monokultur secara signifikan berpengaruh terhadap produktivitas padi gogo pada jarak tanam 3 dan 6 baris.

2. Produktivitas jagung yang ditanam secara monokultur dan tumpangsari 
dengan padi gogo pada jarak 3 -9 baris mempunyai produktivitas yang sama.

3. Tumpangsari jagung dengan padi gogo pada jarak 9 baris mempunyai nilai kesetaraan lahan lebih tinggi dibanding jarak 3 dan 6 baris masing-masing 0.63 dan 0.33 .

4. Analisis usahatani berdasarkan $\mathrm{R} / \mathrm{C}$ rasio terhadap biaya tunai dan biaya total tertinggi pada pola tanam tumpangsari jagung dengan padi gogo jarak tanam 9 baris.

\section{DAFTAR PUSTAKA}

Aisyah, Y. dan N. Herlina. 2018. Pengaruh jarak tanam tanaman jagung manis (Zea mays L. var. saccharata) pada tumpangsari dengan tiga varietas tanaman kedelai (Glycine max (L.) Merrill). Jurnal Produksi Tanaman, 6(1), 66-75.

Alridiwirsah., H. Hamidah, M.H. Erwin dan Y. Muchtar. 2015. Uji Toleransi Beberapa Varietas Padi ( Oryza Sativa L. ) Terhadap Naungan. J. Pertanian Tropik. 2 (2) : 93- 101

Aminah, I.S., D. Budianta, Y. Parto, Munandar dan Erizal. 2013. Tumpangsari Kedelai-Jagung, Jarak Tanam, dan Pupuk Hayati di Lahan Pasang Surut. Prosiding Seminar Hasil Penelitian Tanaman Aneka Kacang dan Umbi. 734-741.

Badan Pusat Statistik. 2018. Hasil Survei Pertanian Antar Sensus (SUTAS) 2018. pp. 49.

Bhato, M.A. 2016. Respon Pertumbuhan dan Hasil Jagung (Zea mays, L.) Varietas Pioner Terhadap Berbagai Takaran Pupuk Kandang Babi dan
Jarak Tanam. J. Savana Cendana. 1 (2) : 85-89.

Dewi, S.S., R. Soelistyono dan A. Suryanto. 2014. Kajian Pola Tanam Tumpangsari Padi Gogo (Oryza sativa L.) Dengan Jagung Manis (Zea mays saccharata Sturt L.). J. Produksi Tanaman. 2 (2): 137-144.

Hafni, T., S. Zakaria dan E. Kesumawati1 2019. Daya Adaptasi Beberapa Varietas Padi Gogo (Oryza Sativa L.) Pada Tingkat Naungan Yang Berbeda. J. Agrista. 23 (3) : 145158.

Hermawati D.T. 2016. Kajian ekonomi antara pola tanam monokultur dan tumpangsari tanaman jagung, kubis dan bayam. Inovasi 18(1): 66-71.

Khairunnisa. 2019. Karakter Morfo Fisiologi Padi Gogo Cekaman Naungan. Tesis Program Magister Agroteknologi. Fakultas Pertanian. Universitas Sumatera Utara. pp. 32.

Lestari, Desi., E. Turmudi dan D. Suryanti. 2019. Efisiensi Pemanfaatan Lahan Pada Sistem Tumpangsari Dengan Berbagai Jarak tanam Jagung dan Varietas Kacang Hijau. J. IlmuIlmu Pertanian Indonesia. 21 (2) : 82-90.

Maghfiroh, J. 2017. Pengaruh Intensitas Cahaya Terhadap Pertumbuhan Tanaman. Prosiding Seminar Nasional Pendidikan Biologi. Jurusan Pendidikan Biologi. Fakultas MIPA. Universitas Negeri Yogyakarta. 51-58.

Noviana, I dan I. Ishaq. 2011. Karakter Hasil Galur dan varietas Jagung Pada MK II di Jawa Barat. Prosiding Seminar Nasional Pengkajian dan Desiminasi Inovasi Pertanian Mendukung Program Strategis Kementerian Pertanian. Cisarua, 9-11 Desember 2010. 1548-1552.

Prawiwi, Y.H. 2012. Produktivitas Kedelai (Glycine max L.) Pada System Tumpangsari Jagung (Zea mays L.) 
Secara Deret Tambah. Skripsi. Program Studi Agroteknologi. Fakultas Pertanian Sebelas Maret. Surakarta.

Putra, J.P.H., K.P. Wicaksono dan N. Herlina. 2017. Studi Sistem Tumpangsari Jagung (Zea mays L.) dan Bawang Peri (Allium purrum L.) Pada Berbagai Jarak Tanam. J. Produksi Tanaman. 5 (5) : 748-755.

Putri, M.P. 2011. Analisis Komparatif Usahatani Tumpangsari Jagung Dan Kacang Tanah Dengan Monokultur Jagung di Kabupaten Wonogiri. Skripsi Fakultas Pertanian. Universitas Sebelas Maret. Surakarta. Pp.69.

Rembang, J.H.W. 2010. Keragaan Tanaman Jagung Komposit Srikandi Kuning Di Kecamatan Tompaso Kabupaten Minahasa. Seminar Regional Inovasi Teknologi Pertanian Mendukung
Program Pembangunan Pertanian Provinsi Sulawesi Utara. 103-110.

Saputri, A. R., Y. Yuwariah, A. Wahyudin dan D. Ruswandi. 2018. Pengaruh Pola Tanam Tumpangsari Jagung (Zea mays L.) dengan Padi Hitam (Oryza sativa L.) terhadap Pertumbuhan dan Hasil Tanaman Jagung di Arjasari Kabupaten Bandung. Jurnal Agrotek Indonesia 3(2): 121-128

Susanti, Anwar S, Fuskhah E, Sumarsono. 2014. Pertumbuhan dan nisbah kesetaraan lahan (NKL) koro pedang (Canavalia Ensiformis) dalam tumpangsari dengan jagung (Zea Mays). J. Agromedia 32(2): 38-44.

Susilo, E. dan Parwito. 2013. Tumpangsari Padi Gogo dan Kedelai Dengan Konsep Leisa: Limbah Pertanian Sebagai Pupuk Organik. J. Agroqua. 11 (2): 21-30.

Yuwariah, Y., D. Ruswandi dan A.W. Irwan. 2017. Pengaruh Pola Tanam Tumpangsari Jagung Dan Kedelai Terhadap Pertumbuhan Dan 